\title{
Peace is not the absence of war but the presence of a relationship founded by God - פשָלוֹם (shalom) in Isaiah and Micah
}

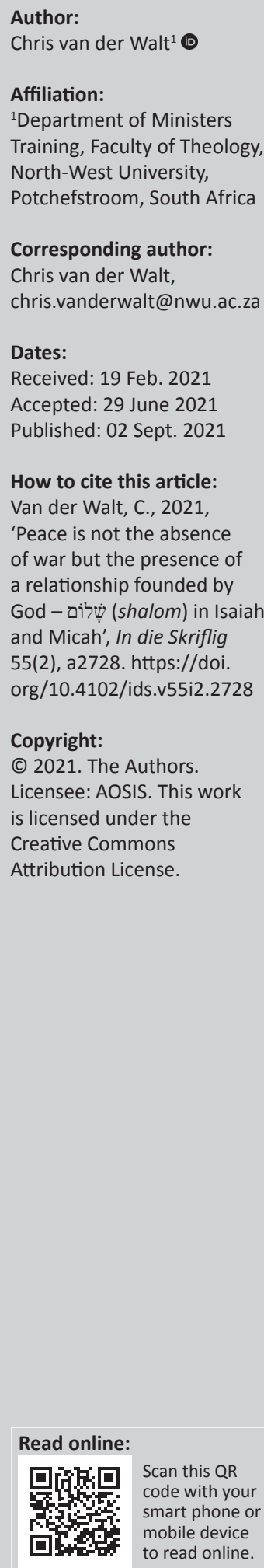

In theology and in general, there are perceptions about peace as the absence of war and strife. However, if these perceptions are measured against what the prophets Isaiah and Micah teach explicitly about it, a different reality is sketched. Isaiah 2:1-5 is widely seen as a vision of peace. However, the concept שָׁלוֹ (shalom [peace]) does not appear in the pericope, but only later in Isaiah 9:5 and then further on throughout the book. The thought of Isaiah 9:5 is repeated in Micah 5:4. The question that needs to be answered is: What is the real meaning of שָׁi் in the Isaiah and Micah passages? To answer the question, all the verses in Isaiah and Micah in which the concept שָ occurs, were first identified in the Biblia Hebraica Stutgartensia. Thereafter, it was placed in cohesive groups. With this information in mind, the way peace was lost in Isaiah and Micah is described. Then the new beginning that God has made, is discussed exegetically in the passages where שָׁ peace was returned. It was found that î is never described in Isaiah and Micah in terms of the absence of a modality such as war, but in terms of relationships. Peace is therefore not a condition established by people, but exists primarily within a relationship between God and people. What the prophets, Isaiah and Micah, teach us about peace should influence our thinking in such a way that our perception of it should be reviewed.

Contribution: The reality of peace, as seen from the perspective of Isaiah and Jeremiah, calls for a line of thought that is not currently at the forefront. Peace should therefore not be seen as a situation that people create. Instead, the biblical view is that it emanates from a relationship that begins with God and is then expressed in relationships with fellow human beings.

Keywords: vision of peace; peace; war; Isaiah; Micah; justice; relationship.

\section{Introduction}

In theology and in general, there are perceptions about peace as the absence of war and strife. Levin (2008-2010) put it as follows:

In the ancient world peace meant the absence of destructive conflicts, just as it does today. But that is a relative definition. Absolute peace is beyond anything we can imagine. It is not even desirable. For civilization and culture owes as much to the conflict of forces as it does to peace. The important thing is that in this conflict 'the balance of power' is maintained. If the balance is upset, chaos gains the upper hand. The ordered world which is essential for successful life would founder in the conflict. Under the modem rule of law, 'the balance of power' is guaranteed by the state's monopoly of force. (p. 29)

As far as the absence of destructive conflicts in Old Testament context is concerned, two passages are normally referred to: Isaiah 2:4 and Micah 4:3. These passages are very similar and is often called a vision of peace. ${ }^{1}$

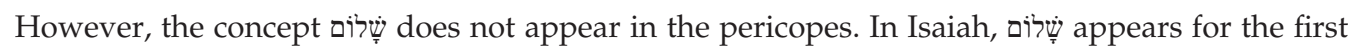
time in 9:5 and then further on throughout the book. The thought of Isaiah 9:5 is repeated in Micah 5:4. The question that needs to be answered, is the following: What is the real meaning of שin in the Isaiah and Micah passages?

The approach in this article, similar to that of Gert Breed to whom this Festschrift is dedicated, is as follows: The light of Scripture is shone on reality and perceptions by way of exegesis. This

1.This is deduced from the prominence of the dictum 'Swords into plowshares' has in academic thinking, for example the proceedings of a colloquium edited by Cohen and Westbrook (2008), articles by Groenewald (2013) and Schmitz (2008). 
leads to an enriched understanding of a text and the practical situation. $^{2}$ In this contribution to Breed's Festschrift, it is a privilege to participate in the pastoral field of study similar to his by listening to both the situation and the text. It will be indicated that peace is more than the absence of conflict as it is quite often portrayed, ${ }^{3}$ and that real peace can only be experienced through servanthood.

\section{Background}

A guideline for this article is the number of articles dealing with peace as described in Isaiah and Micah. This was done from the vantage point that peace is equivalent to 'swords turned into ploughshares'. However, if the concept of 'peace' is studied semantically within the canonical context in the books of Isaiah and Micah, other conclusions about 'peace' could be made.

To show how שָׁלוֹ [peace] is often interpreted, the description of Greever (2016) is given. According to him, שָָל [peace] carries the fundamental meaning of welfare, prosperity or wholeness in the Old Testament. It also refers to the absence of hostility. The term is often used as the antithesis of harm and as a synonym for what is good. When peace is used in the context of warfare, it will likely communicate a mere cessation of war, but not friendship (Mi 3:5). The biblical authors portray the absence of hostilities in a positive sense. Because of his almost constant involvement in warfare, David was therefore not allowed to build the temple. His son

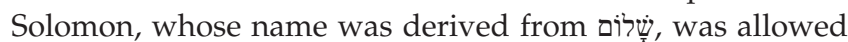
to do so, because the Lord granted him peace from his enemies (1 Ki 5.3,4). As a continuation of this thought, Isaiah prophesied that when the Messiah arrives, he will be called the 'Prince of Peace', because he will achieve lasting peace over his enemies (Is 9:6; Mi 5:5). Greever then concludes with the following statement: 'At this point, God would destroy weapons in the world as they "beat their swords into ploughshares and their spears into pruning hooks" (Is 2:4)'. Greever thus defines ultimate peace as the absence of war, referring to a passage (Is 2:4) in which the word שׁ̇i does not appear. Although Isaiah 2:1-5 is sometimes referred to as a vision of peace, peace is not mentioned in the pericope.

\section{Problem statement and method}

Beuken (2003:94) comments that Isaiah does provide a view towards the future in the revelation he receives (Is 2:1-5). This view shows Yahweh's initiative, which came to fruition in Isaiah 40-66. However, the realisation in Isaiah 40-66 was preceded by a real vision of peace announced in chapter 9 . Unfortunately, the notion of peace in Isaiah 9 is often neglected in research as can be seen from the absence of any publications listed in the EBSCOhost database ${ }^{4}$ specifically

2.In an article by Breed (2014), he indicates that the term Missio Dei is not used consistently in literature and may even lead to misunderstandings. Based on sound exegesis of the Ephesian letter, he then makes a suggestion about the actual meaning of the term in its relation to God.

3.One of the most well-known expressions associated with peace is: 'Swords into ploughshares' which is visually expressed in a well-known sculpture of Evgeniy Vuchetich included in the United Nations Art Collection.

4.From 1981 until 2021, only a few publications discussing peace in the book of Isaiah could be found. The proceedings of a colloquium published and edited by Raymond dealing with peace in this chapter. Because peace is explicitly mentioned in Isaiah 9 and Micah 5, the light it might shed on the actual meaning of peace will be exegetically researched.

Brueggemann (1998:24) directly ties up with the abovementioned view of Beuken that Isaiah, after judgement was pronounced in chapters 1-39, envisages new possibilities for Jerusalem in chapters 40-66. This happens because the prophet looks beyond the coming destruction of Jerusalem to God's long-term goal, and part of that goal is real peace.

What is striking is that peace in the book of Isaiah is first introduced seven chapters later than the 'vision of peace' in 2:1-5. It is in Isaiah 9:5(6) where first time in connection with a person - as it is also done in Micah 5:4(5).

In this article, it will be argued that it is essential to take note of the fact that the actual concept of wìi, in the context of the books of Isaiah and Micah, has a more extensive meaning than the absence of war.

\section{The occurrence of שֶׁ in Isaiah and Micah}

To establish the meaning of 'peace' in Isaiah ${ }^{5}$ and Micah, all the incidences of שָׁל in Isaiah and Micah will first be identified to see which similarities or themes can be found. After that, the two almost identical passages occurring in the books of Isaiah (9:5[6]) and Micah (5:4[5]) will be further investigated to show how the agency of God is essential for peace.

The occurrences of שָׁi in the books of Isaiah and Micah can be found in the following verses in Biblica Hebraica Stutgartensia (the meaning will each time be abstracted and paraphrased):

\section{Occurrences of فำ in Isaiah}

- 9:5 - Prince of Peace;

- 26:3 - Peace to those who trust in Yahweh;

- 26:12 - The Lord will ordain peace;

- 27:5 - If people make peace with the Lord and seek his protection, they will not suffer in battle against him;

- 32:17,18 - The effect of righteousness will be peace and peaceful habitation;

- 33:7 - In the day of reckoning, those who were supposed to announce peace will instead be crying because of the lack of peace as the treaty is broken;

- 39:8 - Hezekiah only wished for peace in his days;

- 41:3 - The conqueror whom Yahweh sent, passes safely (in peace);

Cohen and Raymond Westbrook (2008) provoked a lot of discussion. The title of the proceedings signifies the point of view: 'Isaiah's vision of peace in biblical and modern international relations: Swords into plows'. Another publication with the same vantage point is that of Groenewald (2013) titled 'An exegetical analysis of the vision of peace in the Book of Isaiah (2:1-5)'.

5.For the purposes of this article, the canonical books of Isaiah and Micah are treated as theological unities. To obtain a thorough overview of the problems in the approach to the book of Isaiah in its current form, the following can be consulted: Tiemeyer (2008:167-169), as well as Berges (2012). As far as the final form of the book of Micah is concerned, it is considered to consist of a two-part structure: Micah 1-5 and 6-7. A comprehensive overview is given by Waltke (2007). 
- 45:7 - Yahweh brings about well-being (peace) and creates calamity;

- 48:22 - Yahweh says that there is no peace for the wicked;

- 52:7 - The feet of the messenger who announces peace are beautiful;

- 54:13 - The children taught by God will have peace;

- 57:2 - The righteous shall enter into peace;

- 57:19 - Yahweh will give peace to those He healed;

- 57:21 - There is no peace for the wicked;

- 59:8 - The wicked and unjust does not know the way of peace;

- 60:17 - Peace will be the overseer of the inhabitants of the city of the Lord;

- 66:12 - Prosperity will be extended to the new Jerusalem like a river.

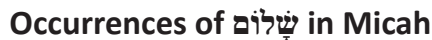

In the book of Micah, the notion appears twice:

- 3:5 - The Lord announces judgement on the prophets who proclaim peace when they are remunerated to do so;

- 5:4(5) - The ruler who will come from Judah will be the one of peace.

When all the passages are considered according to the theme of peace, passages can be clustered under the headings in Table 1.

When a survey is done of the verses in which the concept of peace appears, it is mainly found in a relational way. When there is peace, it is either granted by Yahweh or because of human conduct within their relationship with God. It can therefore preliminary be said that peace should not be thought of as a modality that can be brought about without proper relationships.

\section{Possible meanings of שִׁלוֹם}

In light of the identified passages, it is clear that it is not possible to give an uncomplicated meaning of situations in the Old Testament can be typified as peace. According to commentaries and theological dictionaries, the possible meaning as derived from context range from the absence of war and disorder to the presence of satisfaction, material prosperity and silence (Swanson 1997c:8934).

What is not mentioned in most explanations or definitions of שֶ namely that none of the above-mentioned situations is typified as peace when God is not present.
In connection with this, Carlson (1997:1634) also states that peace has the meaning of total well-being and security associated with God's presence among his people. Peace is also associated with the covenant in the Old Testament and is therefore seen as a gift of God to Israel (Dt 28-30). Peace, however, is determined by Israel's obedience to the covenant.

Gerleman (1997:1340) further points out that Israel's disobedience and iniquity broke the covenant, as well as the peace that existed between them and God. The result was extreme discontent and destruction during exile in accordance with the provisions of the covenant as is evident in Deuteronomy 28. However, the covenant was essentially still maintained by God, and therefore a life with God was still possible after the exile (Dt 30:1-7; Is 54:10).

The false prophets did not take the covenant provisions into account and simply accepted that God would allow his people to prosper regardless of their actions. The general expectation was that Israel would enjoy continuous political peace (Ps 89). Jeremiah seriously warned against this misconception (14:13-16) and, in parallel with Isaiah, announced the coming judgement in the form of the Babylonian exile (Jr 21:7; Is 39:5,6).

Despite the various possibilities of meaning that שָׁ may have, Stendebach (2006:23) demarcates it into two semantic ranges, namely: (1) 'peace and kindness which is the opposite of war and hostility (politically focused)'; and (2) 'Well-being, success and good luck' (emphasising material goods).

This view does not take the relational aspect into account. The following remark from Gerleman (1997) tends to the crux of the matter:

Seldom do we find in the OT a word which to the same degree as שָ can bear a common use and yet can also be filled with a concentrated religious content far above the level of the average conception. (p. 1340)

What needs to be observed is the role that God and religion

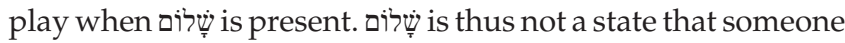
obtains by him- or herself, but emanates from a relationship.

Perhaps the statement by Brueggemann (2001:14) demonstrates the relational matter most clearly when he points out that, in recent times, שָ is used as a summary of the following cluster of words: love, loyalty, truth, grace, salvation, justice, blessing and righteousness. It is of

TABLE 1: Peace passages in Isaiah and Micah clustered according to their bearing on peace.

\begin{tabular}{|c|c|c|c|c|c|}
\hline $\begin{array}{l}\text { 1. The Lord will be the agent } \\
\text { of peace }\end{array}$ & $\begin{array}{l}\text { 2. Those who depend on } \\
\text { the Lord will experience } \\
\text { peace }\end{array}$ & $\begin{array}{l}\text { 3. Those who act righteously } \\
\text { according to the requirements of } \\
\text { the covenant will experience peace }\end{array}$ & $\begin{array}{l}\text { 4. Both calamity and peace } \\
\text { are in the hands of Yahweh }\end{array}$ & $\begin{array}{l}\text { 5. The unjust will not } \\
\text { experience peace }\end{array}$ & $\begin{array}{l}\text { 6. Peace will reign in the } \\
\text { end }\end{array}$ \\
\hline Isaiah 9:5 & Isaiah 26:3 & Isaiah $32: 17,18$ & Isaiah 33:7 & Isaiah 48:22 & Isaiah 60:17 \\
\hline Isaiah 26:12 & Isaiah 27:5 & Isaiah 54:13 & Isaiah 41:3 & Isaiah 57:21 & - \\
\hline Isaiah 45:7 & - & Isaiah 57:2 & Isaiah $45: 7$ & Isaiah 59:8 & - \\
\hline Isaiah 57:19 & - & - & - & Micah 3:5 & - \\
\hline Micah 5:4(5) & - & - & - & - & - \\
\hline
\end{tabular}


importance to note that none of these concepts can exist outside a relationship.

One of the notions that the prophets frequently equate with peace is the blessing thereof which God bestows on the righteous (e.g. Is 9:7; 26:3, 12; 32:17; 39:8; 55:12; 57:2; Ezk $37: 26)$. On the other hand, it is also regularly proclaimed that the unrighteous shall have no peace, as was shown in the cluster of meanings previously mentioned (Is 48:22; 57:21; Jr $6: 14 ; 8: 11,15 ;$ Ezk 13:10, 16).

So peace and the absence of peace link up with righteousness and unrighteousness with God being the judge thereof. This notion is stated by Penchansky (2006-2009) in the following remark:

In a sense, it can be said that God maintains a balance in the universe that induces harmony and well-being. The word שָלוֹם expresses that balance ... When someone violated communal or individual norms ${ }^{6}$, that person tipped the balance away from shalom, threatening the community's prosperity and well-being. By acting against the perpetrator (by execution, banishment, loss or disease), God restored the harmony. (p. 781)

What makes the situation in both Isaiah and Micah different from what Penchansky claims, is the structure of both these books, Isaiah and Micah.

In both these books, God does not merely act against the perpetrator by cutting off the relationship with the guilty party. Quite surprisingly, he also initiates a process that leads to peace by introducing a Messianic figure who is the agent of peace. God's action is therefore not confined to acting against perpetrators, but he also makes a new beginning from a deathlike situation. This is a developmental situation where the relationship progresses from chastisement in exile towards a renewed relationship.

The following section will show how the different possible meanings, as mentioned above, become practical in the history of Israel as it is portrayed by the prophets Isaiah and Micah.

\section{Development of (and the absence thereof) in Isaiah in order to shed light on the theological use of peace in the book of Micah}

Isaiah and Micah were contemporaries, ${ }^{7}$ but they also share elements found in the prophecies of the pre-exilic prophets. From the identified passages and the discussion above, it can be gathered how peace was lost and reintroduced by Yahweh in both Isaiah and Micah. To show how this happened, the following elements in both books will be dealt with:

- Accusations against Israel and Judah that they have broken the covenant (Is 1-39; Mi 1:2-2:13). [Peace lost];

6.The upkeep of norms towards the community and God laid down by Yahweh in his covenant with Israel, is considered to be righteousness.

7.Even though they are contemporaries, Isaiah $40-66$ focuses on a later stage than what Micah focuses on.
- Call for repentance (Is 30:15; Mi 6:8) [Possibility of peace]

- In the absence of repentance, judgement follows (Is 6:11,12; Mi 3:12). [Peace lost];

- Hope beyond judgement and a future restoration is envisioned (Is 6:13b; Mi 2:12-13; 4:1-7; 5:7; 7:11-20). [Peace reintroduced].

\section{Accusations against Israel and Judah that they have broken the covenant (Is 1-39; Mi 1:2-2:13)}

There are many accusations against the people of God in the books of Isaiah and Micah. Both books are also introduced by formulae that call the people of God to appear in judgement before him. In Isaiah 1:2, Yahweh calls for heaven and earth to hear his case against his people. In Micah 1:2, he commands the people to hear and the earth to listen to the Lord witnessing against them. In the passages that follow, the rebellion and transgressions of God's people are stipulated. It is also made clear that, because of these transgressions, there will be consequences. These consequences will be according to the stipulations of the covenant in Deuteronomy 30:19 (Van der Walt 2014).

The conditions of the covenant state that the people of God must show their faithfulness in their relationship with him. If faithfulness is not maintained, God would increasingly withdraw his caring hand from his people and deliver them into the hands of the enemy (Dt 28). When surrendered into the hands of the enemy, they would lose the ease of life they had in the living space that God had provided to them in Canaan (Is 6:11,12). The consequences of breaking the covenant led to a rupture in the relationship between Yahweh and his people. The result was that they lost the land he had given to them as living space. In this land, they were meant to live in such a way that they had a calm and peaceful life.

Even though the prophets of Yahweh proclaimed the guilt of Israel and Judah, the false prophets declared that God would let his people prosper regardless of their actions (Jr 23:16; Mi 3:5). For the false prophets, political peace was supposed to be the order of the day, because the people kept the temple cult. This concept was rejected as false (Is 1:10-17; Jr 7:4-6). The impression that heartless religious rituals could safeguard them from political calamity and the loss of peace was condemned in Isaiah 1:10-15. What they needed to do, was to repent and repair their relationships with Yahweh and their fellow human beings (Is 1:16, 17). In these relationships, they had to represent Yahweh by being faithful, righteous and loving.

\section{Call for repentance (Is 30:15; Mi 6:8)}

The prophets often call the people of God to repent. In Isaiah 1:16 \& 17 they are called to remove their רֵ [evil doings] from before the eyes of Yahweh. Swanson (1997b) defines ำ in this context as:

$\ldots$ an action which is not morally pure or good according to a proper standard, implying this evil hinders or severs a relationship to a person or principle which is proper. (p. 8278) 
In the discussion on 'accusation' broken relationships were the focus. It is also the case with the call to repent - the people are called to repair severed relationships. The evil that the people of God have done, was rooted in a broken relationship that manifested in action towards other members of the people of God, especially vulnerable orphans and widows. These members of the society only had Yahweh to look up to, because they were primarily bound to him in the covenant (Am 3:1, 2). Therefore, Yahweh, saw a violation of the relationship with the vulnerable as violating the requirements of the covenant with him, because the covenant was not only established with some members of the Israelite community, but with them all (Dt 5:2,3).

Not only should the people of God refrain from injustice, but they should also implement justice and righteousness in their lives. These crucial community traits were essential in the covenant society. Therefore, in Isaiah 1:17, the rulers and the people are commanded to seek מִשְָׁׁפט [justice], because justice was displaced by [wickedness] (1:4) Swanson (1997a:6411) makes it clear that עָ y a concept implies guilt in every context where it is used. This guilt always has legal consequences. Luc (1997:351) describes the guilt as predominantly religious guilt. This was because ethical functions were not fulfilled and therefore the word עָ is also used to summarise all sins against God.

Against this background, the call for repentance in Isaiah 30:15 can be looked at. In this sentence, the Holy One of Israel addresses his people with: 'In returning and rest you shall be saved; in quietness and trust shall be your strength.' The historical background of Isaiah 30:15 is that of Israel's dealings with Egypt. They were often tempted to trust Egypt instead of Yahweh (Matthews, Chavalas \& Walton 2000; Is 30:1). Instead of a quiet unshakable faith in Yahweh to whom they were eternally bound in the covenant, they wanted to align themselves with untrustworty human beings. Because of this distrust in Yahweh, they would have to flee before their enemies, which signifies the complete absence of peace (Childs 2001:226).

The same primary thought is also present in Micah 6:8. As in Isaiah 30:15, so it is with Micah. The people of God wanted to influence him through external offerings. Even if they gave their firstborn to him, it was still not what he required in a relationship. Micah 6:8 firstly asks and then answers the question about what God wants from Israel. What he requires is a response from the heart, demonstrating the essential elements of true religion that are evident in the Torah. What Yahweh requires in social matters concerns conduct according to their covenant responsibilities (McComiskey \& Longman 2008:540).

The reason why מִ מִשְָׁ [justly] behaviour is of such importance, is that justness is an attribute of God (Ez 9:15; Neh 9:33; Ps 145:17; Is 26:7; cf. Gn 18:25; Ezk 33:17, 20). Justice is also primarily a concept that can only exist within a relationship. In the relationship, behaviour fitting the requirements of the relationship must be exhibited. It is because Abraham believed the Lord that he reckoned his faith to be righteous. The relationship with God was as it should have been: worthy of trust (Mott 2011:506).

Clark and Mundhenk (1982) aptly summarise the general requirements of the relationship between God and his people:

What the Lord requires is explained in three brief phrases: to do what is just, to show constant love, and to live in humble fellowship with our God. This reply completely ignores the sacrificial system which the speaker in verses 6 and 7 was thinking about, and it expresses God's will in moral rather than ceremonial terms. The prophet's point is that the outward and ceremonial forms of religion should reflect an inner moral relationship with God, and without this relationship, all ceremony is useless. (p. 232)

Despite the calls to repent, Israel and Judah did not respond according to the requirements of the covenant relationship; thus, there were negative consequences. The possibility of peace being introduced into the society was lost, because the relationship between Yahweh and his people was not healed.

\section{In the absence of repentance, judgement follows (Is 6:11,12; Mi 3:12)}

In Leviticus 26 and Deuteronomy 28, the blessings and curses in the treaty formulae are found. These formulae are typical of the ancient Near Eastern legal codes and treaties. The principle is to ensure compliance and goodwill (Matthews et al. 2000). Leviticus 26:6 states that God will grant his people in the land when they uphold the stipulations of the covenant. By adhering to the stipulations, they would experience blessings of agricultural prosperity, peace, population growth and God's presence. Fee and Hubbard (2011:137) describe it as a symbolic return to Eden where God is present in his creation ( $\mathrm{Lv} 26: 12)$. On the other hand, by non-adherence to the stipulations of the covenant, they would experience curses of fear, disease, famine, violence, death, oppression by enemies and exile. Through these experiences, peace would be lost.

These actions against God's people were not because of the initiative of their enemies as if he had no control over it. In Isaiah 41:3, the conqueror whom Yahweh had sent, passed by in peace because Yahweh granted him the opportunity to do so. This can be the case, because history is not only the actions ensuing from human plans and human will. From the beginning, history is subject to the sovereign rule of God. In 596 BC it was Nebuchadnezzar who was allowed to bring fear and trembling to God's people in Jerusalem. In Isaiah 41 it is portrayed how Yahweh allowed a new kingdom to pass by the nations in peace. This time it was the kingdom of Cyrus II who answered the summons of Yahweh to bring an end to the Babylonian exile in 539 BC (Blenkinsopp 2008:197).

It is under the sovereign rule of Yahweh that a new beginning can be made to bring hope beyond judgement. This is due to the covenant relationship, which would not be entirely lost, 
because Yahweh is righteous in keeping the covenant. Therein lies a new beginning and hope for peace.

\section{Hope beyond judgement and a future restoration is envisioned (Is 6:13b; 9:5(6)-7; Mi $2: 12-13 ; 4: 1-7 ; 5: 7 ; 7: 11-20)$}

In keeping the covenant, Yahweh ensures that nobody can accuse him of being unfaithful to his promises (Is 50:1-3). It is his faithfulness that has brought a new beginning out of a situation that implied not only the absence of peace but also death.

Isaiah 9:5(6)-7 is the first passage under discussion, which gives hope for peace beyond judgement with a vision towards future restoration. This text is the first in Isaiah which refers to peace using the term ${ }^{8}$. In this instance, it is found in

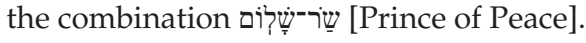

Many commentaries do not pay detailed attention to the individual concepts in Isaiah 9:6 with no exception to

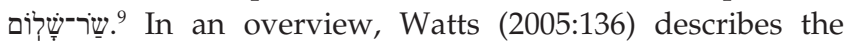
general mood in Isaiah 9:6 as one of hope being introduced with the promise of an heir to the throne of David. Wegner (1992) draws attention to the use of יוֹיע with the following explanation:

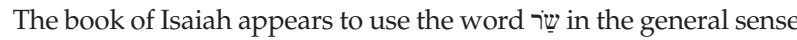
of 'ruler' (cp. i 23, iii 4, 14, xxxii 1) and thus both the terms יוֹ יע: and שַ may be intended to draw a contrast between the 'counsellors' and 'rulers' of the nation of Israel, who are going to lead the nation into shame and defeat (Isa. xxx 1-5, xxxi 1-3), and Yahweh, who will lead the nation wisely and in ways of true peace. (p. 112)

Hope is thus linked to rulers who will destroy peace, but also to Yahweh as the ultimate ruler who will be the agent of peace. Keil and Delitzsch (1996:165), likewise, attribute the removal of peace-disrupting powers to the Prince of Peace. Wildberger (1991:405) remarks that the basic sense of peace is freedom from foreign powers who make war possible by

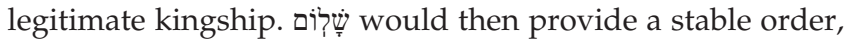
opening up the possibility for development.

Goldingay (2012:71) brings the matter closer to the line established by all the שָׁ passages in Isaiah and Micah when he comments that the leader who will bring peace will be an executor of justice and righteousness. However, he still links shalom to the end of warmongering.

Motyer (1999:103) emphasises the relational aspect of peace, typifying it as being whole or complete. The Prince of Peace would then be harmonious with God and humankind. Young (1976:339) elaborates on this by contrasting ordinary rulers who seek the greatness of their kingdoms in war to the Prince of Peace who removes the cause of war by bringing harmony between God and humanity.

8.There are a number of well-known articles that deal with 'the vision of peace" following Isaiah 2:4 and Micah 4:3. In the pericopes in which these thoughts occur peace is, however, not directly referred to.

9.Commentators, not giving specific attention to the meaning of peace, who were consulted include Otto Kaiser, J.J.M. Roberts, John Oswalt.
The ideas will now be viewed in light of the previously grouped together.

\section{Relevant thoughts derived from the

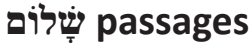

\section{The unjust will not experience peace}

In the first place, those who will know no peace are mentioned in summary. Those who are specifically mentioned, lacked

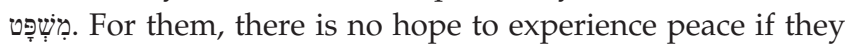
remain in their wicked state of mind. The reason why they are called wicked is that their compatriots suffered under their injustice. They, themselves, will now suffer under the hand of Yahweh who is the perfect judge. Their suffering, however, will not be because of any injustice done by Yahweh. It will be because he acts in accordance with the requirements of the covenant relationship. In their case, the right relationship culminates in Yahweh acting against them, because they acted against those to whom he attached himself in the covenant. In the relationship with him, injustice has no place, and therefore neither do the people who practise it.

\section{Both calamity and peace are in the hands of Yahweh}

God is sovereign. He does not report to anyone or needs to ask anyone for advice or assistance in his actions. This is the case, because he has all power in heaven and earth (Dt 32:39; Is $45: 7)$. Therefore, there can be no circumstances in history over which God has no control (Is 44:7). Circumstances are thus not situations in which the people of God find themselves as victims of events.

In Isaiah 59:1, this point is clearly made when the ability of God is indicated to be undeniable. His hand is not too short to reach into any situation and he could send his people into the calamity of exile by the hand of the Babylonians. He could also rescue his people from exile and send them back to the living space he had promised to Abraham by the hand of his anointed Cyrus (Is 45:1).

\section{The Lord is the agent of peace}

God's sovereignty, trustworthiness and caring lead to his personal involvement in the lives of human beings. Through his personal and faithful keeping of the covenant, he maintained the relationship with his people. Therefore, peace is neither a modality nor a condition, but the result of the interaction between God and his people. The first instance in which the relation is spelt out, is in Isaiah 9:5(6) as has been

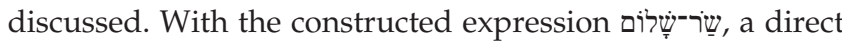
link is established between peace and the agent thereof. A statement, which needs consideration in this regard, is that of Niehr (2004:197) when he compares the title שcommander or translated as prince] with that of עִ עִ [servant]. Although he states that the two titles are not deemed to be synonyms, the term עֶֶָ, in a certain period, referred to members of the royal staff. In the book of Isaiah, the titles do have a theological connection in the sense that the 'servant of Yahweh' is a wellknown theme in the book. It is the servant who brings righteousness to an unrighteous people through his vicarious 
servanthood. It is therefore in line in Isaiah's theology that the Peace-Prince also brings peace through servanthood. It is rightly described in Messianic terms (Is 9:7), because none in Israel or Judah was capable of fulfilling this task, and it can therefore only be attributed to the Lord himself (Is 54:17; 59:16-17).

Micah 5:4(5) parallels Isaiah 9:5(6). In Micah, the agent of peace is indicated by וזהיזה זֶה שָׁלוֹ [he shall be the one of peace] (Waltke 2007:286). Literally, the clause is 'he will be peace'. There is a considerable amount of discussion in scholarly circles about the historical possibilities of the identity of this person. What almost all commentators agree on, though, is that the Person who is the origin of peace is the Messiah (Achtemeier 2012:343; Alfaro 1989:55).

Consequently, Micah's proclamation about the origin of peace is not the same as that of the false prophets. Their impression of peace was in accordance with their military views, setting their hope in human effort. They had false security of a 'peace' based on the force of arms rather than on social justice and reform, contradicting the true Messianic hope for peace (Alfaro 1989:56).

The last passage to be considered with regards to God's agency in peace is Isaiah 26:12 where it is said that Yahweh

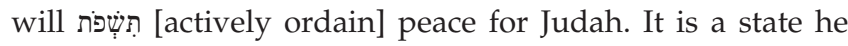
brings into existence that did not exist before. All the accomplishments of Israel came by the actions of Yahweh, and peace is no exception.

\section{Peace will reign in the end}

When Isaiah is viewed in general, chapters 1-39 is about the announcement of the coming Babylonian exile. In chapters 40-66, a new beginning is envisaged and realised - first during the Persian period, but also in eschatological terms. In chapter 60 the future glory of Zion is depicted when the glory of God will be the focus of all the people flocking to Zion which, 'in days to come', will be the most important centre of instruction.

In this context, peace is said to be the overseer, and righteousness, the taskmaster (Is 60:17). What is mentioned is the superiority of everything concerning what was previously experienced. Gold will replace iron, and peace and righteousness will be the order of the day. Peace will be the superior power emanating from God to make a substantial change in the lives of those in Zion (Hamilton 1999:733)

\section{Conclusion}

As indicated in the problem statement, the perception of peace in both social and theological thinking is that of the absence of destructive conflicts. The two texts to which these perceptions are theologically traced are Isaiah 2:4 and Micah $4: 3$. However, if the concept of peace is explored in the rest of Isaiah and Micah, other inferences can be made.
From the rest of the chapters in Isaiah and Micah, it has become clear that only entails the absence of weapons of war, but specially emanates from a person's presence. This stands against the common perception that peace can be won in war. It is only in relation to God, and then with one another, that peace between human beings can exist. Nowhere in Isaiah or Micah is peace the product of human endeavour. Therefore, peace cannot be accomplished by force.

On the one hand, the only involvement that human beings have in the realm of peace is to bring an absence of peace. On the other hand, through God's presence and actions, a state of existence can be experienced which is much more than the mere absence of war and strife. It can be compared with the words of Isaiah 66:13, as long as a child is with his or her loving mother, he or she has peace. Therefore, peace does not depend on circumstances, but on the relationship with the person in whose presence one is. Peace is therefore received from God and distributed in a servant capacity to other people. Only when God's presence is established in the hearts and minds of people, will there be no need for implements of war.

\section{Acknowledgements Competing interests}

The author declares that he has no financial or personal relationships that may have inappropriately influenced them in writing this article.

\section{Author's contributions}

The author declares that he is the sole author of this research article.

\section{Ethical considerations}

This article followed all ethical standards for research without direct contact with human or animal subjects.

\section{Funding information}

This research received no specific grant from any funding agency in the public, commercial, or not-for-profit sectors.

\section{Data availability}

The authors confirm that the data supporting the findings of this study are available within the article.

\section{Disclaimer}

The views and opinions expressed in this article are those of the authors and do not necessarily reflect the official policy or position of any affiliated agency of the author.

\section{References}

Achtemeier, E., 2012, Minor prophets, Baker Books, Grand Rapids, MI. Alfaro, J.I., 1989, Justice and loyalty: A commentary on the Book of Micah, Eerdmans, Grand Rapids, MI. 
Berges, U., 2012, The Book of Isaiah: Its composition and final form, Sheffield Phoenix, Sheffield

Beuken, W., 2003, Jesaja 1-12/übersetzt und ausgelegt von Willem A.M. Beuken; unter Mitwirkung und in Übersetzung aus dem Niederländischen von Ulrich Berges, Herder, Freiburg.

Blenkinsopp, J., 2008, Isaiah 40-55: A new translation with introduction and commentary, Yale University Press, New Haven, CT.

Breed, G., 2014, "n Kritiese blik op missio Dei in die lig van Efesiërs', In die Skriflig 48(2), Art. \#1707, 10 pages. http://dx.doi.org/10.4102/ids.v48i2.1707

Brueggemann, W., 1998, Isaiah 1-39, Westminster John Knox, Louisville, KY.

Brueggemann, W., 2001, Peace, Chalice Press, St. Louis, MO.

Carlson, C., 1997, 'Peace', in W.A. Elwell (ed.), Baker encyclopedia of the Bible, p. 1634, Baker Book House, Grand Rapids.

Childs, B.S., 2001, Isaiah: A commentary, Westminster John Knox, Louisville, KY.

Clark, D.J. \& Mundhenk, N., 1982, A translator's handbook on the book of Micah United Bible Societies, London.

Cohen, R. \& Westbrook, R., 2008, Isaiah's vision of peace in biblical and modern international relations: Swords into plowshares, Palgrave Macmillan., New York.

Fee, G.D. \& Hubbard, R.L., 2011, The Eerdmans companion to the Bible, Eerdmans, Grand Rapids, MI.

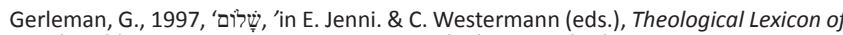
the Old Testament, pp. 1337-1348, Hendrickson, Peabody, MA.

Goldingay, J., 2012, Isaiah, Baker, Grand Rapids, MI.

Greever, J.M., 2016, 'Peace', in J.D. Barry (ed.), The Lexham Bible Dictionary, Lexham Press, Bellingham.

Gregory, T.M., 2009, 'Peace', in M.C. Tenney (ed.), The Zondervan Encyclopaedia of the Bible, pp. 747-750, Zondervan, Grand Rapids, MI.

Groenewald, A., 2013, 'An exegetical analysis of the vision of peace in the Book of Isaiah (2:1-5)', Verbum et Ecclesia 34(2), Art. \#866, 7 pages. http://dx.doi. org/10.4102/ve.v34i2.86

Hamilton, V.P., 1999,' ' 'דפקִָ in R.L. Harris, G.L. Archer \& B.K. Waltke (eds.), Theological Wordbook of the Old Testament, pp. 731-733, Moody Press, Chicago, IL.

Keil, C.F. \& Delitzsch, F., 1996, Isaiah, Hendrickson, Peabody, MA.

Levin, C., 2008-2010, 'Old Testament Religion: Conflict and peace', Annual of the Japanese Biblical Institute,vol xxxiv-xxxvi, pp. 29-54, Tokyo.
Luc, A., 1997, 'עִ עִ ('āwōn)', in E. Willem Vangemeren (ed.), New International Dictionary of Old Testament theology \& exegesis, p. 351, Zondervan Publishing House, Grand Rapids, MI.

Matthews, V.H., Chavalas, M.W. \& Walton, J.H., 2000, The IVP Bible background commentary: Old Testament, InterVarsity Press, Downers Grove, IL.

Mccomiskey, T.E. \& Longman, T.I., 2008, Micah, Zondervan, Grand Rapids, MI.

Mott, S.C., 2011, 'Justice', in M.A. Powell (ed.), The HarperCollins Bible Dictionary (revised and updated), p. 506, HarperCollins, New York, NY.

Motyer, J.A., 1999, Isaiah: An introduction and commentary, InterVarsity Press, Leicester

Niehr, H., 2004, 'שָ', in G.J. Botterweck, H. Ringgren \& H.-J. Fabry (eds.), Theological dictionary of the Old Testament, vol. 14, pp. 190-215, William B. Eerdmans Publishing Company, Grand Rapids, MI.

Penchansky, D., 2006-2009, 'Retribution', in K.D. Sakenfeld (ed.), The new interpreter's dictionary of the Bible, vol 4, pp.781-782, Abingdon, Nashville, TN.

Schmitz, B., 2008, 'Kommt, lasst uns ziehen hinauf zum Berg JHWHs (Mi 4, 2): Jerusalemwallfahrt und Friedenvision, Bibel und Liturgie, 82, 242-245.

Stendebach, F.J., 2006, שלום, in G.J. Botterweck \& H. Ringgren (eds.), Theological dictionary of the Old Testament, vol.15, pp. 15-49, Eerdmans., Grand Rapids.

Swanson, J., 1997a, 'פָiı', in Dictionary of Biblical languages with semantic domains: Hebrew (Old Testament), p. 6411, Logos Research system, Oak Harbor.

Swanson, J., 1997b, 'צר (rōa)', in Dictionary of Biblical languages with semantic domains: Hebrew (Old Testament), p. 8278, Logos Research system, Oak Harbor.

Swanson, J., 1997c, 'שלום', in Dictionary of Biblical Languages with semantic domains: hebrew (Old Testament), p. 8934, Logos Research system, Oak Harbor.

Tiemeyer, L., 2008, 'Recent currents in research on the prophetic literature', The Expository Times 119(4), 161-169. https://doi.org/10.1177/0014524607085988

Van der Walt, C., 2014, 'The deaf cannot see: An accumulation of blindness and deafness as combined theme in Isaiah 42 and 43', In die Skriflig/In Luce Verb 48(2), 6. https://doi.org/10.4102/ids.v48i2.1764

Waltke, B.K., 2007, A commentary on Micah, William B. Eerdmans Publishing Company, Cambridge.

Watts, J.D.W., 2005, Isaiah 1-33, Word Books, Dallas, TX.

Wegner, P.D., 1992, 'A re-examination of Isaiah Ix 1-6', Vetus Testamentum 42, 1. https://doi.org/10.1163/156853392X00233

Wildberger, H., 1991, Isaiah: Isaiah 1-12, Fortress Press, Minneapolis.

Young, E.J., 1976, The Book of Isaiah volume 1, William B. Eerdmans, Grand Rapids, MI. 